\title{
Using cognitive maps to investigate fishers' ecosystem objectives and knowledge
}

\author{
Magali Prigent $^{a}$, Guy Fontenelle ${ }^{a}$, Marie-Joëlle Rochet ${ }^{b, ~ *}$ and Verena M. Trenkel ${ }^{b}$ \\ ${ }^{a}$ Pôle Halieutique, Agrocampus-Rennes, 65 Rue de St Brieuc, CS 84215, 35042 Rennes Cedex, France \\ ${ }^{b}$ Département Ecologie et Modèles pour l'Halieutique, IFREMER, B.P. 21105, Nantes Cedex 03, France \\ *: Corresponding author : Marie-Joëlle Rochet, email address : Marie.Joelle.Rochet@ifremer.fr
}

\begin{abstract}
:
This paper presents a survey of French Eastern English Channel fishers' observations of the past and current state of the marine ecosystem and their wishes for the future, as a first step towards formulating management objectives. Twenty-nine semi-directive interviews were carried out in June 2006 among fishers and shellfish farmers. Cognitive maps proved useful to formalise their experience and knowledge. Most interviewees mentioned a decrease of the resource in recent years and pointed out the presence of several problems, such as pollution, degradation of the ocean floor and harmful impacts of human activities, including fishing. The indicators used by the fishers as the basis to form their opinion were similar to those generally used by scientists for assessing the state of exploited marine populations and communities (average fish length, CPUE, fished biomass...); additional indicators were the timing and duration of fishing seasons.
\end{abstract}

Keywords: Fisher knowledge; Ecosystem approach to fisheries; Cognitive map; Stakeholder interview; Management objectives; Eastern English Channel 


\section{Introduction}

The ecosystem approach to fisheries management relies, among others, on two important pillars [1]:

- Availability of indicators to be monitored and evaluated against benchmarks usually named reference points, either targets or limits, related to management objectives. At an ecosystem level it will be difficult to set these reference points only based on science, because the available knowledge is not sufficient and because they will unavoidably involve trade-offs between various ecosystem components. Defining targets and limits for the ecosystem approach will entail value judgement and decision.

- Involvement of ecosystem users and other stakeholders to be efficient. This involvement is slowly being implemented. For example, the European Union established Regional Advisory Councils, consisting mainly of stakeholders, which will increasingly participate in fisheries management [2].

However, for effective stakeholder involvement, a shared understanding of objectives and a common knowledge base for management has to be built [3]. The first step is to elucidate the differences in understandings of the resource system and management objectives [3]. Building trust among users of a common resource is a complex process that needs time until a real dialogue can emerge $[4,5]$. Fisheries science faces the challenge to investigate fishers knowledge and objectives and to contrast them with scientific evidence and current policy objectives. For this new field, new tools need to be developed and implemented. The purpose of this study was twofold: first, to elucidate fishers' management objectives and formalising their ecosystem knowledge; second, to investigate the potential of cognitive mapping as a tool for fisheries system investigations.

An increasing number of publications deal with stakeholder consultation. Fishers' representatives have been asked to rank management objectives for several European fisheries $[6,7]$ and for the ecosystem [8]. The ranking was done using the analytical hierarchy process, in which a predetermined list of objectives is ranked based on pair-wise scoring of preferences. However, methods for formulating these objectives in the first place still have to be designed. Fishers themselves were surveyed about the opportunity and design of marine protected areas on the California coast [9], and about their views regarding the health of the North Sea ecosystem and its current fisheries management system [10]. These studies used semi-directive interviews among participants selected either by the 'snowball' technique (to identify the most knowledgeable fishers, in the California study) or by selecting a representative sample of European fishers in the North Sea. Although we recognise the value of semi-directive interviews and their qualitative analysis such as manual coding [10] for collecting and analysing stakeholders views, we believe that there is room for the complementary use of more formal methods. Cognitive maps are such a tool: interviewees are asked to draw a bubble diagram of a situation or problem, with arrows indicating the main determining factors including their direction and influence strength [11-15]. This helps the interviewees to list all factors that seem important to them and formalise and rank their views on a complex problem.

Here cognitive maps were used to investigate French fishers' knowledge and objectives for the Eastern English Channel ecosystem (hereafter: the Channel). Fishers from other European countries working in the area were not considered in this study. The Channel is exploited by a diversity of fleets [16] and there is a series of environmental concerns in this region that supports an intense maritime traffic, receives effluents from several large cities and is exploited for gravel extraction [17]. Skippers of the main fishing fleets and shellfish farmers from different ports were consulted to build a representative picture of the users of the Channel. We tried to include both young and experienced fishers, who might have different views on the ecosystem. To investigate how they perceived the ecosystem they live on, they were asked to draw its limits on a map, and to appraise its actual state. They were also asked about the perceived changes and their causes, summarising their views in a cognitive map. Finally, to investigate their expectations and help to formulate management objectives, including a desirable ecosystem state, they were asked how they foresee the future of the Channel, what should be primarily preserved, and what might be done to achieve this. Cognitive maps proved useful to underline the complex view of fishers on the ecosystem, including the influences of a variety of human activities (not only fishing) on resource state and the influence of ecosystem state on fishing activities. All these components have to be considered in setting objectives for fisheries management. 


\section{Materials and methods}

\subsection{Sample selection}

To get a representative picture of the diversity of views, the various factors which might influence perception have to be taken into account. Participants were selected according to their current métier, age, and port. A métier is defined as the use of a particular fishing gear to target one or several species at a given time in a certain area [18]. It was expected that people practising different métiers would have different perceptions of the ecosystem they exploit because they do not have the same interests and they fish in different areas or habitats. Eight principal métiers were identified in the Channel (Figure 1): bottom, shrimp and pelagic trawling, gill net, fish and scallop dredging, and shrimp and cuttlefish potting $[16,19]$. Shellfish farmers were also interviewed to investigate their potentially complementary perspective. Aiming at a total of 40 interviews, the number of interviews by category was selected proportional to number of vessels or farms in recent years. Because the métiers "fish dredging" and "shrimp potting" had negligible weights, they were not interviewed. The sample was also stratified according to seniority in each métier (Table 1). In total, 29 professionals could be interviewed in the following harbours: Boulogne-sur-mer, Le Tréport, Dieppe, Honfleur, Trouville, Porten-Bessin and Grandcamp.

\subsection{The interview process}

All consultations were carried out by the same interviewer using semi-directive interviews and cognitive maps. There was no predefined list of questions; rather, an interview protocol specifying the range of topics to be covered, namely the current state of the ecosystem, the driving factors, the indicators used for evaluating changes, and stakeholder expectations (Appendix 1). This approach let the interviewees decide how they wanted to address all issues and develop the points most important and relevant to them. The interviews started with a general presentation of the study and its objectives. The subject of the study was well received on the whole except for the oyster farmers and four fishers who refused to participate in the study. The refusals were explained either by an excess of investigations within this region by scientific teams, and a pessimistic view of the future of fishing, or merely by a lack of time. Then, the interviewees were invited to speak of themselves to identify the values and references that govern their perception. To understand and to be able to interpret the remarks of the stakeholders, it is essential to know which area they refer to. Therefore, they were asked to delimit the Channel on a map. A pilot interview with a fisherman in Boulogne-sur-mer showed that the term "ecosystem" could be misunderstood. To avoid this problem, a definition of the term was first presented in all subsequent interviews. The ecosystem was defined as a system formed by an association or community of interacting living organisms (plants, animals and micro-organisms) in their physical environment. Next the interviews proceeded to more specific questions (listed in Appendix 1).

At the end of the interview, each fisher drew his own cognitive map. A cognitive map is a qualitative model of a system. The map consists of concepts and causal relationships between these concepts [12]. A causal relationship like " $A \rightarrow B$ " means $A$ is the explanation of $B$ or $B$ is the consequence of $A$. The relationships can be positive (an increase of $A$ results in an increase of $B$ ) or negative (an increase of $A$ results in a decrease of $B$ ) denoted by a sign " + " or " $-"$ above the arrow. The relative strength of the relationships (three levels) and time scale (three levels) were also indicated. Figure 2 shows an example cognitive map obtained during this study. As recommended by Özesmi [20], the interviewer built her own cognitive map before carrying out the interviews. This enabled the interviewer to be aware of her own mental representation concerning the study object and helped to avoid being unconsciously influenced by it during the interviews. To represent stakeholders' views, the concepts and the relationships of a cognitive map must be spontaneously formulated or must be the answer to an open question [21]. Therefore, during the interviews, the fishers decided which were the most important factors that affected the ecosystem. The concepts to be included in the cognitive map were not imposed i.e. no list was pre-established [22]. This method does not produce concepts directly comparable between cognitive maps as structured methods do.

All interviews (1-1.5 hours each) were recorded with permission of the interviewees. This made it possible to replay the recordings and pay attention to tone, silence, hesitation and laughter as all these expressions are important for interpreting an interview [23]. A word-by-word transcript was produced for all recordings. 


\subsection{Analysis methods}

A thematic content analysis of answers was conducted to transcribe the distinctiveness of each interview and identify similar subjects referred to by different words [24]. Thus, this analysis looks for the thematic consistency among interviews. General topics were established based on all transcripts and the opinions of all interviewees were tabulated. The answers were also analysed by métier.

With regard to cognitive maps, the great heterogeneity of concepts can make the inter-map analysis difficult. The first step in the joint analysis of cognitive maps consists in analysing the semantic variability of terms and expressions used by the interviewees to establish an ontology: a hierarchically structured set of terms for describing a domain [25]. This requires analysing all concepts and grouping them by meaning. Then, we defined generic terms that gather all the interviewees' terms having the same meaning under a common name. For example, fisher A mentioned 'catch' while fisher B used 'production' basically to say the same thing, thus the two terms were grouped under the generic term 'quantities fished'. At last, the generic terms were hierarchically structured according to fields, topics or categories. For example, 'overfishing' and 'spawning grounds' at the lower level, belong to the 'state of fisheries resources' at the next level, which in turn is an element of 'fisheries resources' and finally of the 'marine ecosystem' at the highest level (see Appendix 2).

Based on the common ontology, an inter-map analysis was carried out. The relative importance of each term of the ontology was evaluated from the citation frequency. Then, the cognitive maps of the interviewees were aggregated by métier to form average maps. For this analysis, all métiers using trawls were grouped. The aggregation of several cognitive maps is expected to yield a better representation of the system [26] and was used to identify differences and similarities among métiers. The first step to aggregate cognitive maps is to transform individual maps into adjacency matrices of the form $A=\left[a_{i j}\right]$, where the generic concepts $u_{i}$ are listed both on the vertical and horizontal axis to form a square matrix. When a generic concept $u_{i}$ influences a generic concept $u_{j}, a_{i j}$ takes the value of the strength of the link between both concepts. Table 2 shows the scoring for the example in figure 2 . Individual cognitive maps at level 2 of the ontological tree and the corresponding matrices were generated using the computer program by Poignonec [14]. Average maps by métier were then obtained by calculating the arithmetic mean of the adjacency matrices.

We analysed individual and average cognitive maps using descriptors from graph theory. This approach is useful for comparing the structure of maps among groups (here métiers). The number of concepts $(\mathrm{N})$ and number of connections (C) in the cognitive maps were counted. The density (D), as an index of connectivity and complexity, was calculated as $D=\frac{C}{N^{2}}$ [12]. We also investigated the concept types and their contributions. There are three types of concepts in a cognitive map: transmitter concepts with only outgoing arrows that influence other concepts, receiver concepts with only incoming arrows and ordinary concepts that are mixed.

\section{Results}

\subsection{The ecosystem's boundaries}

Most of the commercial fishers drew approximately the boundaries of ICES VIId division for the Channel system. However, five people (shellfish farmers and gill netters) referred to a smaller region, which matches the more restricted area they exploit.

\subsection{What is the current status of the marine ecosystem in the Channel?}

All 29 interviewees answered this question. To define the current state of the marine ecosystem in the Channel, they based their opinions on their own observations and most of them made comparisons with the past. Owing to the various interests, experiences and knowledge of the consulted stakeholders, the answers were diverse. However, most of them thought that the ecosystem was damaged.

Three types of opinions were expressed about the health of the living resources:

For $76 \%$ of the interviewees, the fisheries resources were in a poor state. According to them, biomass decreases year by year for most exploited species. They have been noticing catch reductions and a lack of fish for about the last five years. Some of them even compared the Channel to a "desert" or used strong words to express their pessimism. 
«On ne peut pas dire que c'est riche. [...] Parce que, pour moi, d'année en année ça baisse quand même un peu. » ${ }^{1}$

«Les ressources, de toute façon ça ne va pas en s'améliorant. D'année en année, ça décline. Et puis on a l'impression que quand il y a un truc, quelque chose qui ne va pas, une espèce, c'est tout qui suit. » ${ }^{2}$

$17 \%$ of the stakeholders did not give a general answer but detailed the trend of some fish species. Most of them noted a decrease in flatfish species (sole and plaice), gadoids (cod, whiting), and more recently cuttlefish. In contrast, they noticed that spider crab, edible crab and sea bass were doing better and scallops remained stable.

Two people, a young fisherman who had just bought a boat and a mussel farmer, were optimistic about the marine resources and thought there was no problem at all.

Despite the differences, all interviewees agreed about common views. In recent years, significant changes in the fish community have occurred in the Channel. First of all, the stakeholders emphasised changes in species' presence. Subtropical species, such as red mullet or squid, increased in abundance while boreal species like cod decreased. For most of the fishers, these trends are largely attributable to climate change.

« Avant on était sur du cabillaud et sur du merlan [...] Maintenant on est passé sur du rouget barbet, de l'encornet. Si vous voulez, le fait d'avoir changé de climat, ça a changé les espèces de poissons.» ${ }^{3}$ «Maintenant que les eaux se réchauffent, il y a du poisson qu'avant on ne voyait pas dans le coin et maintenant il vient par ici. Vu que ça se réchauffe, le poisson il remonte pour chercher de la fraîcheur. II y a du poisson à l'inverse qui est parti. La morue tout ça, on n'en voit plus. » ${ }^{4}$

Most stakeholders say that the increase in sea temperature leads some species to move to more suitable waters. Only two interviewees thought that climate did not have any impact on fisheries resources. A second trend was mentioned by more than one third of the interviewees who noticed changes in fishing periods: shorter and/or delayed fishing seasons. As an example, most fishers quoted the sole fishing season but some extended their remarks to all fisheries resources.

The interviewees also talked about habitats. Ninety percent mentioned water quality. Many people observed signs of pollution from various origins. Every day, the fishers observe a significant presence of litter like "plastic bags, old shoes, pieces of television or pieces of washing machine...". These wastes are mainly encountered at greater depths or close to the coast and river mouths. The litter might also come from maritime traffic and the fishers themselves. Several people noted an increase in plastic and bottles. Harbour dredging and the non-treatment of collected mud are perceived as considerable sources of pollution. A higher mortality of mussels during the clearing periods was ascribed to mud discharges three miles off the coast. They also mentioned industrial, agricultural or urban pollution though this kind of pollution is not directly visible. However, some people observed a proliferation of seaweeds and linked this phenomenon to eutrophication by nitrogen or phosphate. Lastly, the interviewees feared oil and chemical pollution. They remember the oil-spill events by Erika, Amoco Cadiz and Evoli Sun and think that such events would have irreversible consequences on the fauna and flora of the Channel, which they see as a semi-closed sea. Nevertheless, the majority of fishers acknowledged a recent improvement of water quality compared to the past. The construction of water treatment plants and the rising awareness of fishers and the general public would explain this progress. Regarding the ocean bottom, some said that it "has changed" or "has been degraded" due to erosion, impacts of some fishing gears (beam trawls, dredges...) and gravel extraction.

\subsection{What are the indicators used for determining ecosystem state?}

Another goal of the interviews was to understand how commercial fishers evaluate the state of the marine ecosystem. Twenty-five people answered this question referring to four indicators:

Quantities fished (catch biomass) were quoted by 13 interviewees. According to them, the annual catch decreases year by year.

\footnotetext{
1 "You cannot say it is rich [... ] Because, for me, year after year it decreases yet a little."

2 "The resources are not improving anyway. Year by year, they decline. And then, you get the impression when there is one species, something which is not well, then everything follows."

3 "Before, we went for cod and whiting. [...] Now, we go for red mullet, squid. If you want, changing climate changed the fish species. "

4 "Now that waters are warming up, there is fish we did not see around here before and now it comes here. Given it is warming up, the fish seeks coolness further North. Some species on the contrary went away. Cod, all that, we do not see them any more "
} 
Mean length of the fish caught is the second most quoted indicator. The fishers who mentioned this indicator pointed out that, at the present time, fish are smaller compared to when they started fishing, or that the proportion of large fish has decreased.

« Avant on ramassait... Je veux dire... Si on avait 20 caisses à bord, on avait 40 caisses sur le pont. On ramassait que les gros. Les petits on remettait ça à l'eau. Tandis que maintenant on va ramasser 10 caisses mais c'est que du petit. Donc forcément la taille elle diminue. » ${ }^{5}$

Many fishers fear that fish do not have any more time to multiply. Two thirds of the fishers who mentioned fish size as an indicator of the state of the resource also noted quantities fished. Some explained the link between both factors:

« Les espèces que l'on pêchait avant étaient... eh... disons en taille moyenne étaient plus grosses. Et actuellement ce que l'on pêche c'est petit. La quantité est toujours la même... enfin la quantité, au poids non, au nombre d'individus, la quantité est apparemment la même, mais la taille a diminué et donc le tonnage diminue. ${ }^{6}$

Productivity: only three interviewees talked about their productivity as being an indicator of the resource state. These people declared to have reduced productivity compared to earlier times.

Fishing season is another indicator used by the fishers, who refer to implying the date of the beginning of the fishing season or its duration. They noticed a delayed arrival of some species and shorter seasons.

The mussel farmers assessed the ecosystem state in relation to mussel growth and quality. In France, the quality of water for aquaculture is classified based on bacteriological measurements on shellfish. No problems were signalled for the Somme Bay, the area where the interviewed mussel farmers work. Yet, these mussel farmers have noticed a reduction of mussel quality and an increase in mortality during harbour clearings. Lastly, they noticed an increased mussel growth since they started in the business and connected this with higher food availability.

\subsection{Fishers' expectations}

Twenty-seven people stated their wishes and expectations. Most were doubtful regarding the current management system and thought that the current measures were ineffective. Some pointed out a lack of homogenisation among countries. Others felt that European regulations did not protect the resource but favoured some métiers. They requested more appropriate and more gear-specific regulations. A lack of communication with fishers was also underlined. Many fishers wished for more "bottom-up" decision-making in which they could be involved in the management process.

All agreed that effective measures to preserve the resource and habitat are needed, including:

- Setting appropriate and more realistic quotas. For example, according to the fishers, mackerel and herring are abundant in their waters and the quotas are not high enough in relation to the biomass. Moreover, they fear that foreign fleets will remain forever in the Channel. Fishers do not understand catch limitations on semelparous species like cuttlefish as these will die after reproduction even if they are not fished (this is correct as long as juvenile cuttlefish are not caught together with adults).

- Improving control of fishing activities. Most stakeholders noted that many people do not comply with quotas, mesh sizes or other regulations. Some pointed out that monitoring and/or enforcement are insufficient and unfair. On the other hand, some talked about control harassment and a too finicky application.

- Protecting juvenile fish by a better compliance with legal mesh sizes and minimum landing sizes.

- $\quad$ Protecting spawning areas by prohibiting gravel extraction and trawling in coastal areas.

- Preserving water quality. Fishers note a recent improvement in water quality but hope that efforts to limit pollutions will be continued.

- Introducing limited fishing seasons. All fishers considered that temporary closures could be an effective measure for many species but were concerned by the potentially induced economic impacts. Such a measure would not be accepted without a financial compensation.

\footnotetext{
5 " Before we caught... I mean... If there were 20 fish boxes on board, there were 40 boxes of fish on deck. We kept only the big fish. We returned the smaller ones to the sea. While now, we catch 10 boxes of fish but it is only small fish. Thus, inevitably, the size decreases. "

6 " Species that we fished before were... eh... let's say in mean size....were larger. And currently what we fish is smaller. The quantity is still the same... actually the quantity, not by weight, by number, the quantity seems to be the same, but the size has decreased and therefore the gross weight decreases
} 


\subsection{What are the factors and human activities that impact this ecosystem?}

When interviewees expressed their views about the current state of the Channel ecosystem, they often talked about the past and the changes they had observed. Comparing past to present gives an idea of ecosystem functioning and allows to establish a short list of system components. This list was completed during the construction of cognitive maps and identifies the factors that can impact fisheries resources. All fishers highlighted several threats and most of them admitted that over-fishing contributed, among others, to the current problems.

Overall 188 terms were defined on 27 maps. An ontological tree with 118 generic terms was built by grouping the interviewees' terms with a similar meaning and deleting over-detailed terms. The final tree is divided into three principal branches and has four levels of increasing specification. The three branches correspond to three systems that fishers consider to describe the ecosystem: (i) the marine ecosystem, (ii) the socio-system, and (iii) external factors (Appendix 2).

Once the ontological tree was built, the citation frequency by métier of all terms of level 3 was calculated by counting the corresponding citations of level 4 terms. For example, if a stakeholder wrote "drought" on his cognitive map, this factor would be counted for the corresponding term of level 3 , i.e. the term "climate". The same calculation was repeated for level 2, counting the number of level 3 terms (Figure 3). For the majority of interviewees, commercial fishing impacts the marine ecosystem, but other factors, like pollution, climate change, industrial and maritime activities play a role as well. Interestingly, the terms in direct relation with fishing are not among the most quoted factors (Figure 3). These factors and their relationships with the other components of the system are detailed below.

\subsubsection{Fishing}

On cognitive maps, the fishers mentioned 45 times a concept linked to commercial fishing but only two included recreational fishing. However, several others talked about the impact of this fishing activity during the interview. According to them, recreational catches are not negligible and are sold on an unofficial market. Some recreational fishers sell their catches below market prices and this hinders sales by the commercial fishers. Commercial fishers were most exasperated by recreational fishers not being subject to the same constraints (quotas, licensing and fishing method restrictions).

Fishers underlined the effects of commercial fishing on the resource and on the sea floor. They said that it must be considered as one of the factors that explain the deteriorated state of fish stocks. Most interviewees thought that the current situation can be partly explained by too large catches and discards, which threaten fish reproduction. Others said that there were too many fishers for the size of the area. All the fishers from Boulogne-sur-mer stressed that the situation has worsened since fishers from the adjacent North Sea came into the Channel. In the North Sea, recent fishing closures and recovery plans led to some fishers moving southward. Furthermore, the Danish seine and beam trawls used by Dutch and Belgian vessels were often criticised. Many French fishers thought that these two fishing gears scrape the sea floor, sweep larger areas than traditional gears, and destroy spawning areas. Some people also blamed passive nets because, according to them, the activity is little managed and lost nets keep catching fish (ghost fishing). Some fishers are thought to have considerably increased net lengths. As for the gill-netters, they disapproved of trawling as being nonselective and leading to the discard of large amounts of fish. No interviewee felt personally responsible for the current situation and most ascribed the problems to other stakeholders. This can be illustrated by a discussion between two fishermen. One of them said: « Mais bon, on jette la pierre sur les autres, on n'est peut être pas trop honnête, non plus. » ${ }^{7}$. His colleague answered: «Oh, ouais, peut être... Mais bon, je crois... on est peut être loin d'être les pires. " ${ }^{8}$ For others, they pay for the errors and abuses made in the past. One of the fishermen declared: "Tous les gens qui sont en retraite maintenant, eux ils ont bien profité de la chose... Ils partiraient avec nous en mer et ils verraient ce qu'il reste et ce qui tombe sur le pont, ils feraient une syncope.» ${ }^{9}$

The rapid pace of technological developments in fisheries was cited as a key problem by some fishers. For example, GPS and other navigation instruments make it now possible to trawl much closer to shipwrecks than before and exploit the higher abundance there without risking to lose the net. More efficient fishing gears have led to an increase in fishing effort.

Several fishers also talked about economic factors that constrain their behaviour. In the current economic crisis they face, they have to take a short-term view to save their business. Some

\footnotetext{
${ }^{7}$ We reproach others. But we are probably not so clean, either.

${ }^{8}$ Yeah, it is possible... But I believe we are probably far from being the worst

${ }^{9}$ All people who are now retired, they took benefits... Would they go at sea with us and see what is left and arrives on deck, they would faint
} 
acknowledged they do not comply with quotas and regulations because their expenses are too high. They know their behaviour is not consistent with the need for resource protection and they face a dilemma.

\subsubsection{Industrial and maritime activities}

The interviewees underlined the negative impact of industrial and maritime activities on the ecosystem and fish stocks. The Channel is under pressure from several uses. During discussions, the most often cited activities were gravel extraction, underwater cables associated with offshore wind farms, maritime traffic, and agriculture. Gravel extraction was criticised by the fishers for inducing a high mortality of benthic organisms, a destruction of spawning areas and significant changes of marine habitats and topography.

« II y a eu des extractions du côté anglais et les collègues sont unanimes pour dire que c'est des mers ruinées. Ce n'est même pas la peine d'y aller. II n'y a plus rien. Ca a été dévasté alors que c'était des bons lieux de pêche avant. " ${ }^{10}$

Some fishers included future projects of offshore wind-farms and underwater cables within their cognitive map. For one of them, the wind-farms would have direct impacts on fishing and would create conflicts. For others, they would produce noise and vibrations that could induce fish movements. Lastly, these constructions require underwater cables that are feared to have negative effects on the resource. Finally, maritime traffic and agriculture were connected to pollution and water quality; which explains why both these factors are viewed negatively.

\subsection{Cognitive maps: towards a picture of the Channel ecosystem}

The cognitive maps aggregated by métier (Fig. 4) and the investigation of the type of concepts (Table 3) summarise these results and allows a comparison among métiers. All fishing métiers had a rather similar perception. The most important links were drawn among the following concepts: fisheries resources, commercial fishing, other human activities, environmental factors and damaged habitat. Strikingly, fisheries resources receive many negative impacts, mainly from commercial fishing, other human activities, environmental factors and habitat state (Fig. 4, Table 3). By contrast, fisheries resources have much less influence on other concepts. For example, they generally do not have a positive impact on commercial fishing or economic factors (Table 3). Fishers see themselves exploiting a threatened resource that can merely sustain them. The only noticeable exception to this pessimistic picture was the scallop dredgers who think environmental policies can have a positive influence on fisheries resources, which then favours commercial fishing and economic factors (Fig. 4, Table 3). The scallop fishery in the Channel is well managed with fishers more involved in the management process compared with the other fishers working within this area; the stock is in relatively good shape, giving these fishers a profit from their activity, especially in 2006 after two strong year-classes (E. Foucher, personal communication, 2006). Commercial fishing and other activities were identified to impact habitat state by a majority of métiers, except scallop fishers (Table $3)$.

The mussel farmers perceived the ecosystem differently. They quoted factors related to only six fields and interestingly commercial fishing was not one of them. The descriptors calculated from the individual cognitive maps (Fig. 5) confirmed this. Although the mussel farmers mentioned a similar total number of concepts as the other métiers, they displayed fewer connections. The density of their cognitive map was thus lower, but this may be because only two mussel farmers were interviewed.

\section{Discussion}

This survey proved to be helpful to capture fishers' objectives for the French Channel fisheries, but failed to provide contours for an ecosystem reference state. The main ecosystem components believed by fishers to be important to fisheries were biomass and size of commercial species, ecosystem health including by-catch species, water quality and habitat protection, climate change, governance and economics. These objectives agree generally with those identified by Mardle et al. [6] for the same system. A noticeable exception is the improvement of safety and labour conditions issue,

10 "There were extractions on the English side and all colleagues agree that these areas are ruined. It is not worth going there anymore. There is nothing left. These previously good fishing areas have been devastated." 
which were never mentioned in our study. Profitability was also not directly mentioned, although both income and expenses were. Mardle et al. list the minimisation of conflict among groups of fishers as a key objective for the English Channel. Consistently, from this study it appeared that there were conflicts between different métiers, but also between French and foreign fishers. Further comparisons of identified objectives can be made. Raakjær Nielsen and Mathiesen [7] investigated stakeholders' preferences on management objectives for the Danish sand eel and Norway pout fishery in the North Sea; in addition to the objectives identified by Mardle et al. [6], the issue of non-human consumption fishing was important for certain groups of stakeholders. The omission of this issue in the current study is easily explained by the fact that there is no important fishery for fish meal in the Channel. Overall, the expectations outlined by the surveyed fishers are in accordance with the objectives generally recommended by international agencies [27-29]. In particular, they include the objectives of the European Union Common Fisheries Policy [30]. They are actually broader, as they also include environmental considerations that go beyond fisheries policy. This is consistent with previous studies in the North Sea, the US and in tropical fisheries [31-33], which also demonstrated that fishers have a more complex view of ecosystem, including abiotic drivers and various human activities, than fisheries scientists and managers have. In that sense they think more 'ecologically'.

The second objective of this study was to try and establish a reference state for the Channel ecosystem. Unfortunately, based on the results of this survey it is difficult to even outline a reference state. This confirms the conclusion by Wilson et al. [33], who found that local ecological knowledge across a range of systems was not sufficient to quantitatively determine historical changes. Much more formalised methods such as norm curves for predefined ecosystem indicators are probably required to outline acceptable levels [34]. In our study, the interviewees expressed a general feeling that things were better before, but this before was not always accurately defined even if most had spent more than two decades exploiting the system (the mean seniority per fisher was 22 years). A common problem encountered in questionnaire or face-to-face surveys relates to the so-called recall bias. This effect tends to bias answers for events that occurred farther in the past. The problem has been studied in some details in the context of estimates of recreational catches based on selfreporting [35]. The question how many years ago the ecosystem was considered in a satisfactory state and what that state might have looked like will be difficult to determine based on these interviews. However, as the fishers cited quite detailed observations concerning recent changes, in future work we will compare their observations with independent results from scientific studies. This will allow us to establish whether fishers' knowledge is coherent with scientific studies. Mackinson and van der Kooij [36] demonstrated that the perception of fish abundance can depend on the surveying strategy, which is generally randomly distributed for scientific surveys while fishers specifically target hot spots they know.

The indicators used by the interviewed fishers to evaluate the health of the ecosystem were, by decreasing order, fished biomass, mean length in the catch and fishing season and to a lesser degree productivity. In this respect, Channel fishers differed from tropical fishers who generally think that size structure and species composition is a more reliable information than catch rate [33]. This difference might be caused by differences in the scale of fisheries and variability in catches. However, the first two indicators used by fishers, total biomass and mean length, are part of the suite of indicators proposed by scientists for implementing the ecosystem approach to fisheries management [37]. Changes in the fishing season seem to be a new indicator that would be worth exploring further. The mussel farmers additionally mentioned mussel growth and quality. In coastal waters where aquaculture takes place, mussel growth and quality might be suitable indicators to monitor.

Overall, the interviews reveal a rather pessimistic view of fishers on the ecosystem they exploit. They feel it is in a poor state owing to various human activities that impact both the resource and its habitat. They generally put the blame for degradation on others: other activities, other métiers or other countries. It would be interesting to compare the French fishers' views with those of fishers from other countries who work within the same area. This finding is also consistent with previous studies where fishers mentioned other fisheries to affect their resources [31, 33]. The general attitude of blaming somebody else for the situation, coined 'buck-passing', is a major ingredient of the conflicts between fishers and authorities throughout Europe [38]. Moving to an ecosystem approach makes more explicit the number and variety of stakeholders who share the resource. Fishers agree with the ecosystem approach guidelines generally calling for a higher stakeholder involvement in governance [1]: they hope for a better management system, with more participation, equity, and compliance. This will be necessary to solve the increased number of conflicts created by the recognition of multiple uses, not only fishing, but it will require the evolution of the management systems [38].

We now turn to investigate the potential bias introduced by the chosen methods. The sampling scheme was stratified by métier with the number of interviewees proportional to the importance of the métier. Hence the average cognitive maps were based on different sample sizes, ranging from 2 to 
10. To evaluate the impact of sample size on the complexity of the average map, we calculated the number of maps required for the métiers with the largest number of maps (10 maps for trawls and 7 for multi-métier) to include all seven concepts of level 2 of the ontological tree. On average (based on randomly choosing maps without replacement), five and four maps had to be aggregated in order to cover all seven concepts for trawling and multi-métiers respectively. Similarly for the number of connections drawn on a cognitive map, the mean number of connections stabilised once about 5-6 maps were averaged (Fig. 6). Thus conclusions regarding the complexity or importance of concepts for the different métiers have to be interpreted with care, as not enough people were interviewed to construct a stable average map, apart from the métiers trawls and multi-métiers.

During semi-structured interviews, each interviewee freely answers the questions according to his own priorities and values. He can lie, convey a message or keep secret some opinions. There is no way to detect this during the interview. In this study, we have taken all replies at face value. Tape recording of all interviews proved essential as it allowed us to identify verbal and non-verbal messages that were not necessarily noticed during the discussion. It is also necessary to put one personal opinions aside and to maintain the dialogue. Therefore it is essential to get the interviewee to explain his views in detail by asking the same questions in other words and to invite him to clarify any contradictions [23]. The limits of the thematic content analysis that leads to the ontological tree lie in the interpretation of the results. This analysis is subjective as it requires outlining topics and identifying themes among heterogeneous statements. Nevertheless, this method has largely proved its utility and reliability $[14,39]$. Similar problems can also occur during the construction of the cognitive map. As already mentioned, by choosing an approach which did not impose a list of predefined terms, we expected to improve the reliability of the cognitive maps, but there is no way to tell whether this was actually the case. Finally we recognise that the cognitive maps we obtained are the representation of a person at a given moment. It might be expected that if we asked the same people to draw another cognitive map later, the result might be somewhat different as the interviewees had time to think about it in the mean time.

Studies such as the present one are probably going to be repeatedly undertaken while the ecosystem approach to fisheries management develops, as stakeholder involvement clearly will be key to its success. Cognitive maps were a useful complement to the semi-structure interviews. First, they helped each interviewee to complete their list of the factors relevant to the ecosystem and important to their activity. Second, they prompted them to organise these factors into a coherent view and to clearly state the causal relationships between system components. Third, because they can be aggregated across people, cognitive maps provide a summary of the perception of a complex system within a group. The picture delivered by the cognitive maps is consistent with the analysis of fishers' discourse: they tell the same story in a more compact and structured way, although they do not convey the detailed subtleties expressed during the interviews. Finally, cognitive maps ease the comparison between groups of people. All this would be much more difficult with strictly qualitative discourse data. Cognitive maps also contribute to build a qualitative model of a fisheries system that can be analysed by mathematical methods [40] or used to design indicator suites to be used for ecosystem-based fisheries management [41]. Therefore we encourage this family of methods to be further developed and used.

\section{Conclusions}

The interviewed fishers showed a comprehensive understanding of the ecosystem and, consistently, mentioned a wide range of objectives for an ecosystem approach to fisheries management in line with those put forward by international agencies. Although they complained about a lack of communication with fisheries managers, the building of a shared understanding of management objectives and a common knowledge base may not be a remote aim. To some extent, fishers are ready for the ecosystem approach and management institutions lag behind. The latter have to create arenas to negotiate a common ground [33], that is, discuss and agree about objectives and causal relationships. For the latter purpose, cognitive maps proved useful to structure qualitative knowledge.

\section{Acknowledgements}

We thank all commercial fishers who agreed to be interviewed and shared their knowledge and views. We would like also to thank all people who contributed to this study by their comments and advice. 
The practical experience of Emilie Rostiaux and Jérôme Quinquis was valuable to target the persons to be interviewed. Denis Poignonec helped us with the cognitive maps. Our colleagues at IFREMER Boulogne-sur-mer and Port-en-Bessin also gave us the benefit of their experience and knowledge of the Channel. Finally we thank an anonymous referee for his helpful comments on a previous version of this manuscript. This study was partially funded by EC-project IMAGE (Contract FP6 - 044227).

\section{References}

[1] Garcia SM, Cochrane KL. Ecosystem approach to fisheries: a review of implementation guidelines. ICES Jounal of Marine Science 2005;62(3):311-18.

[2] European Union. Council Decision of 19 July 2004 establishing Regional Advisory Councils under the Common Fisheries Policy (2004/585/EC). Official Journal of the European Union 2004;L 256:17-22.

[3] Degnbol P. Science and the user perspective: The gap co-management must address. In: Wilson DC, Raakjær Nielsen J, Degnbol $\mathrm{P}$ The fisheries co-management experience. Accomplishments, challenges and prospects. Dordrecht: Kluwer Academic Publishers, 2003. p. 31-49.

[4] Ostrom E. Governing the commons Oxford University Press, 1990 (280 pp.).

[5] Runge CF. Institutions and the free rider: the assurance problem in collective action. Journal of Politics 1984;46:154-81.

[6] Mardle S, Pascoe S, Boncoeur J, Le Gallic B, García-Hoyo JJ, Herrero I, Jimenez-Toribio R, Cortes C, Padilla N, Nielsen JR, Mathiesen C. Objectives of fisheries management: case studies from the UK, France, Spain and Denmark. Marine Policy 2002;26:415-28.

[7] Raakjær Nielsen J, Mathiesen C. Stakeholder preferences for Danish fisheries management of sand eel and Norway pout. Fisheries Research 2006;77:92-101.

[8] OSPAR Commission. OSPAR stakeholder workshop towards finalisation of Ecological Quality Objectives (EcoQOs) for the North Sea, Report 2005/243. OSPAR Commission 2005.

[9] Scholz A, Bonzon K, Fujita R, Benjamin N, Woodling N, Black P, Steinback C. Participatory socioeconomic analysis: drawing on fishermen's knowledge for marine protected area planning in California. Marine Policy 2004;28:335-49.

[10] Hatchard JL, Gray TS, Mikalsen KM. European Fisheries Ecosystem Plan: stakeholder consultation, Report Deliverable 2. European Union 2003.

[11] Cossette P. Cartes cognitives et organisations Les Editions de L'ADREG, 2003 (327 pp.).

[12] Özesmi U, Özesmi SL. Ecological models based on people's knowledge: a multi-step fuzzy cognitive mapping approach. Ecological Modelling 2004;176:43-64.

[13] Adrianto L, Matsuda Y, Sakuma Y. Assessing local sustainability of fisheries system : a multicriteria participatory approach with the case of Yoron Isaland, Kagoshima prefecture, Japan. Marine Policy 2005;29:9-23.

[14] Poignonec D. Apport de la combinaison "cartographie cognitive - ontologie" dans la compréhension de la perception du fonctionnement d'un écosystème récifo-lagonaire de NouvelleCalédonie par les acteurs locaux. Rennes, France: Ecole Nationale Supérieure Agronomique de Rennes, 2006 (366 pp.).

[15] Mackinson S, Curtis H, Brown R, McTaggart K, Taylor N, Neville S, Rogers S. A report on the perceptions of the fishing industry into the potential socio-economic impacts of offshore wind energy developments on their work patterns and income, Report 133. Cefas 2006.

[16] Guitton J, Dintheer C, Dunn MR, Morizur Y, Tétard A. Atlas des pêcheries de la Manche Editions IFREMER, 2003 (216 pp.).

[17] Jones LA, Irving R, Cosgrove ARP, Coyle MD, Guilliland PM, Murray AR. Eastern Channel Marine Natural Area Profile: A contribution to regional planning and management of seas around England English Nature, 2004 (106 pp.).

[18] Tetard A, Boon M, Bennett D, Berthou P, Bossy S, Casey J, De Clerk R, Delpech J-P, Dintheer C, Giret M, Large P, Latrouite D, Lemoine M, Millner RS, Morizur Y, Ozanne S, Palmer D, Pawson M, Pickett G, Vince M. Catalogue international des activités des flottilles de Manche, approche des interactions techniques, Report RI DRV 93-040. IFREMER 1993.

[19] Leblond E, Daurès F, Berthou P, Bermell S, Merrien C, Demaneche S. Synthèse des flottilles de pêche 2003. Flotte mer du Nord-Manche-Atlantique Ifremer, 2004 (54 pp.).

[20] Özesmi U. Conservation strategies for sustainable resource use in the Kizilirmak delta in Turkey: Faculty of the graduate school of the university of Minnesota, 1999 (253 pp.).

[21] Cossette P, Audet M. Mapping an idiosyncratic schema. Journal of management studies 1992;29:325-47. 
[22] Allard-Poesi F. Cartes cognitives : pour ne pas jeter le bébé avec l'eau du bain. In: AIMS, editor. $V^{\mathrm{e}}$ conférence internationale de management Stratégique, Lille, France, 1996.

[23] Beaud S, Weber F. Guide de l'enquête de terrain : produire et analyser des données ethnographiques. Nouvelle édition Editions la Découverte, 2003 (356 pp.).

[24] Blanchet A, Gotman A. L'enquête et ses méthodes : l'entretien Nathan, 1992 (128pp.).

[25] Swartout B, Patil R, Knight K, Russ T. Toward distributed Use of a Large-Scale Ontologies. Ontological Engineering. AAAI Spring Symposium Series, 1997. p. 138-48.

[26] Eden C, Jones S, Sims D. Thinking in Organizations The Macmillan Press, 1979.

[27] FAO. Indicators for sustainable development of marine capture fisheries, Report 8. FAO 1999.

[28] EEA. Environmental performance indicators for the European Union: http://themes.eea.europa.eu/indicators/, 2003.

[29] ICES. Guidance on the application of the ecosystem approach to management of human activities in the European marine environment, ICES Cooperative Research Report 273. ICES 2005.

[30] C.E.C. Council Regulation 2371/2002 of 20 December 2002 on the conservation and sustainable exploitation of fisheries under the Common Fisheries Policy. OJ L 2002;358/59 31.12.2202.

[31] Delaney AE, McLay HA, van Densen WLT. Influences of discourse on decision-making in EU fisheries management: the case of North Sea cod (Gadus morhua). ICES J. Mar. Sci. 2007;64(4):80410.

[32] van Densen WLT, McCay BJ. Improving communication from managers to fishers in Europe and the US. ICES Jounal of Marine Science 2007;64:811-17.

[33] Wilson DC, Raakjær J, Degnbol P. Local ecological knowledge and practical fisheries management in the tropics: A policy brief. Marine Policy 2006;30:794-801.

[34] Smyth RL, Watzin MC, Manning RE. Defining acceptable levels for ecological indicators: an approach for considering social values. Environmental management 2007;39(301-315).

[35] Tarrant MA, Manfredo MJ, Bayley PB, Hess R. Effects of recall bias and nonreponse bias on self-reporting estimates of angling participation. N. Am. J. Fish. Manage. 1993;13:217-22.

[36] Mackinson S, van der Kooij J. Perceptions of fish distribution, abundance and behaviour: Observations revealed by alternative survey strategies made by scientific and fishing vessels. Fisheries Research 2006;81:306-15.

[37] Rochet MJ, Trenkel VM. Which community indicators can measure the impact of fishing? a review and proposals. Canadian Journal of Fisheries and Aquatic Sciences 2003;60:86-99.

[38] Schwach V, Bailly D, Christensen A-S, Delaney AE, Degnbol P, van Densen WLT, Holm P, McLay HA, Nielsen KN, Pastoors MA, Reeves SA, Wilson DC. Policy and knowledge in fisheries management: a policy brief. ICES J. Mar. Sci. 2007;64(4):798-803.

[39] Bardin L. L'analyse de contenu, 11ème édition ed. PUF, 2003 (296 pp.).

[40] Dambacher JM, Li HW, Rossignol PA. Qualitative predictions in model ecosystems. Ecological Modelling 2003;161:79-93.

[41] Rochet MJ, Trenkel VM, Forest A, Lorance P, Mesnil B. How could indicators be used in an ecosystem approach to fisheries management?, ICES CM 2007/ R: 052007. 
Tables

Table 1. Sampling design and realised samples. The number of participants is the number of vessels or farms carrying out the métier (based on Guitton et al. 2003 and Leblond et al. 2004).

\begin{tabular}{|c|c|c|c|c|}
\hline \multirow{3}{*}{ Métier } & \multirow{3}{*}{$\begin{array}{l}\text { Number of } \\
\text { participants }\end{array}$} & \multirow{3}{*}{$\begin{array}{l}\text { Sampling } \\
\text { objective }\end{array}$} & \multicolumn{2}{|c|}{ Realised samples } \\
\hline & & & \multicolumn{2}{|c|}{ Fishing experience } \\
\hline & & & $<20$ years & $>20$ years \\
\hline Bottom trawl & 557 & 12 & 4 surveys & 5 surveys \\
\hline $\begin{array}{c}\text { Shrimp bottom } \\
\text { trawl }\end{array}$ & 49 & 2 & & 2 surveys \\
\hline Pelagic trawl & 82 & 2 & 1 survey & \\
\hline Scallop dredge & 263 & 6 & 1 survey & 3 surveys \\
\hline Gill net & 357 & 8 & 2 surveys & 2 surveys \\
\hline Cuttlefish pot & 163 & 4 & & 1 survey \\
\hline $\begin{array}{l}\text { Shellfish } \\
\text { farmers }\end{array}$ & 275 & $\begin{array}{c}6 \text { surveys } \\
\text { (2 mussel } \\
\text { farmers, } \\
4 \text { oyster farmers) }\end{array}$ & $\begin{array}{c}2 \text { surveys } \\
\text { (mussel farmers) }\end{array}$ & \\
\hline Multi- métier & l & l & $\begin{array}{c}3 \text { surveys } \\
\text { bottom trawl + scallop dredge: } \\
1 \\
\text { gill net + cuttlefish pot: } 2\end{array}$ & $\begin{array}{c}3 \text { surveys } \\
\text { bottom trawl + scallop dredge } \\
1 \\
\text { scallop dredge + gill net: } 1 \\
\text { gill net + cuttlefish pot: } 1\end{array}$ \\
\hline
\end{tabular}


Table 2. Adjacency matrix coded for the cognitive map shown in Fig. 2.

\section{Consequences}

\begin{tabular}{|c|c|c|c|c|c|c|c|c|}
\hline Causes & $\begin{array}{c}\text { Fisheries } \\
\text { resource } \\
\mathrm{s}\end{array}$ & $\begin{array}{c}\text { Pollutio } \\
n\end{array}$ & $\begin{array}{c}\text { Number } \\
\text { of } \\
\text { vessels }\end{array}$ & $\begin{array}{l}\text { Fish } \\
\text { sale } \\
\text { s }\end{array}$ & Imports & $\begin{array}{l}\text { Various } \\
\text { expense } \\
\text { s / taxes }\end{array}$ & $\begin{array}{l}\text { Regulation } \\
\text { of fishing } \\
\text { activities }\end{array}$ & $\underset{\mathrm{e}}{\mathrm{Climat}}$ \\
\hline $\begin{array}{l}\text { Fisheries } \\
\text { resources }\end{array}$ & 0 & 0 & 0 & 0 & 0 & 0 & 0 & 0 \\
\hline Pollution & -3 & 0 & 0 & 0 & 0 & 0 & 0 & 0 \\
\hline $\begin{array}{l}\text { Number of } \\
\text { vessels }\end{array}$ & -3 & 2 & 0 & 0 & 0 & 0 & 0 & 0 \\
\hline Fish sales & 0 & 0 & -3 & 0 & 0 & 0 & 0 & 0 \\
\hline Imports & 0 & 0 & 0 & -3 & 0 & 0 & 0 & 0 \\
\hline $\begin{array}{l}\text { Various } \\
\text { expenses / } \\
\text { taxes }\end{array}$ & 0 & 0 & -1 & 0 & 0 & 0 & 0 & 0 \\
\hline $\begin{array}{l}\text { Regulation } \\
\text { of fishing } \\
\text { activities }\end{array}$ & 0 & 0 & -2 & 0 & 0 & 0 & 0 & 0 \\
\hline Climate & $+2 /-2$ & 0 & 0 & 0 & 0 & 0 & 0 & 0 \\
\hline
\end{tabular}


Table 3. Descriptors of individual cognitive maps by métier with the number of interviewees in brackets: percent citations for three types of concepts by métier. Transmitter concepts only have outgoing arrows and receiver concepts only incoming arrows in a cognitive map; ordinary concepts have both.

\begin{tabular}{|c|c|c|c|c|c|c|c|}
\hline Métier & $\begin{array}{l}\text { fisheries } \\
\text { resources }\end{array}$ & $\begin{array}{l}\text { damag } \\
\text { ed } \\
\text { biotope }\end{array}$ & $\begin{array}{l}\text { commercial } \\
\text { fishing }\end{array}$ & $\begin{array}{l}\text { other human } \\
\text { activities }\end{array}$ & $\begin{array}{l}\text { economic } \\
\text { factors }\end{array}$ & $\begin{array}{l}\text { environment } \\
\text { al policy }\end{array}$ & $\begin{array}{l}\text { nvironmental } \\
\text { factors }\end{array}$ \\
\hline & \multicolumn{7}{|c|}{$\%$ ordinary concept } \\
\hline \multirow{2}{*}{$\begin{array}{l}\text { Trawls (10) } \\
\text { Scallop } \\
\text { dredge (3) }\end{array}$} & 90 & 90 & 40 & 20 & 20 & 0 & 30 \\
\hline & 67 & 33 & 100 & 0 & 67 & 33 & 33 \\
\hline \multirow{4}{*}{$\begin{array}{l}\text { Gill net (4) } \\
\text { Mussel } \\
\text { farming (2) } \\
\text { Multi-métier } \\
\text { (7) }\end{array}$} & 50 & 100 & 100 & 0 & 25 & 50 & 0 \\
\hline & 50 & 100 & 0 & 0 & 0 & 0 & 0 \\
\hline & 57 & 57 & 100 & 14 & 0 & 14 & 14 \\
\hline & \multicolumn{7}{|c|}{$\%$ transmitter concept } \\
\hline Trawls & 0 & 0 & 30 & 70 & 10 & 40 & 50 \\
\hline $\begin{array}{l}\text { Scallop } \\
\text { dredge }\end{array}$ & 0 & 0 & 0 & 33 & 0 & 33 & 67 \\
\hline Gill net & 0 & 0 & 0 & 75 & 0 & 25 & 50 \\
\hline $\begin{array}{l}\text { Mussel } \\
\text { farming }\end{array}$ & 0 & 0 & 0 & 100 & 0 & 100 & 50 \\
\hline \multirow[t]{2}{*}{ Multi-métier } & 0 & 29 & 0 & 57 & 43 & 29 & 57 \\
\hline & \multicolumn{7}{|c|}{$\%$ receiver concept } \\
\hline \multirow{2}{*}{$\begin{array}{l}\text { Trawls } \\
\text { Scallop } \\
\text { dredge }\end{array}$} & 10 & 0 & 20 & 0 & 30 & 0 & 10 \\
\hline & 33 & 0 & 0 & 0 & 0 & 0 & 0 \\
\hline \multirow{2}{*}{$\begin{array}{l}\text { Gill net } \\
\text { Mussel } \\
\text { farming }\end{array}$} & 25 & 0 & 0 & 0 & 0 & 0 & 0 \\
\hline & 50 & 0 & 0 & 0 & 100 & 0 & 0 \\
\hline Multi-métier & 29 & 0 & 0 & 0 & 29 & 0 & 0 \\
\hline
\end{tabular}




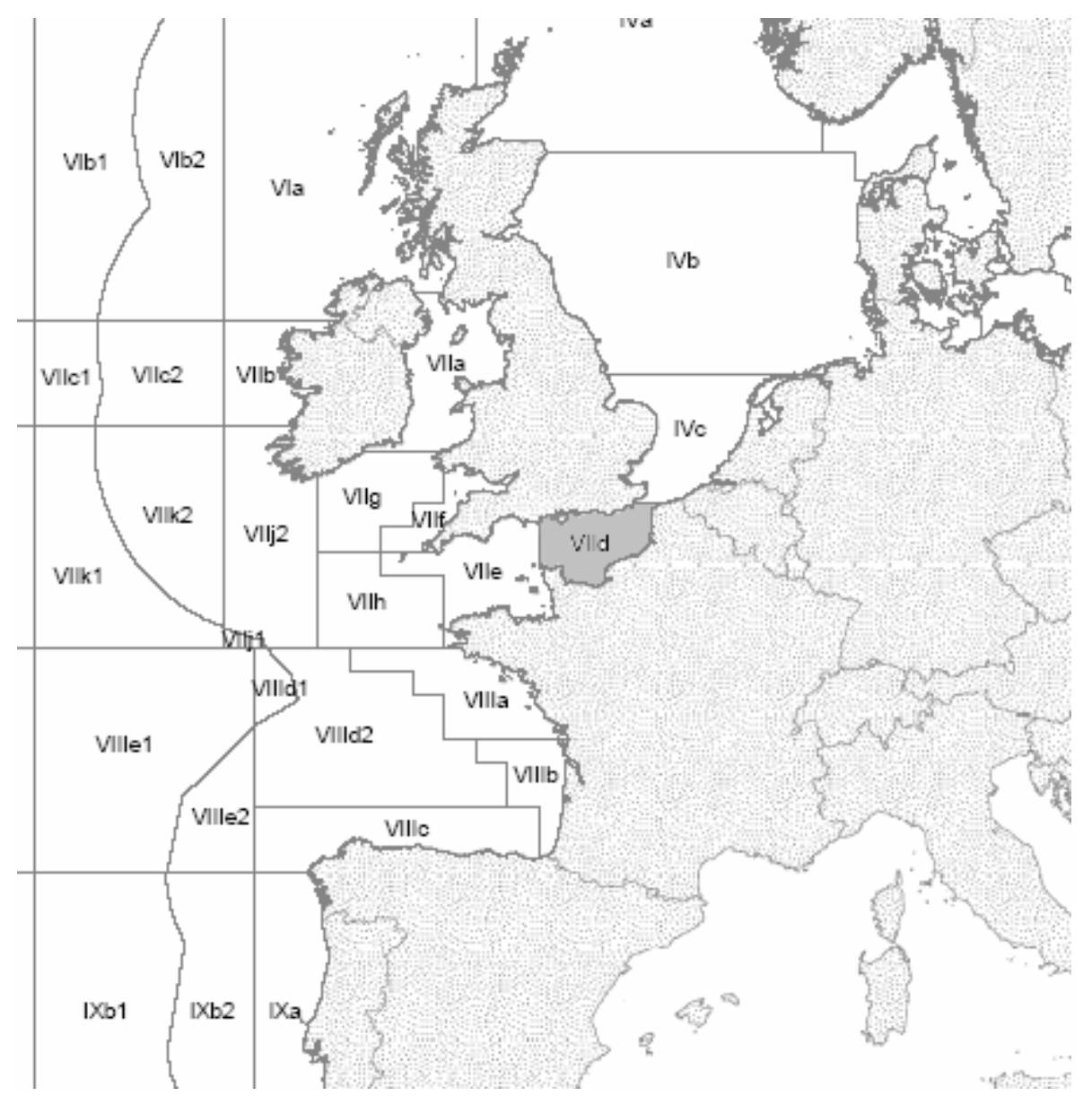

Fig 1. Location of study area Eastern English Channel. 


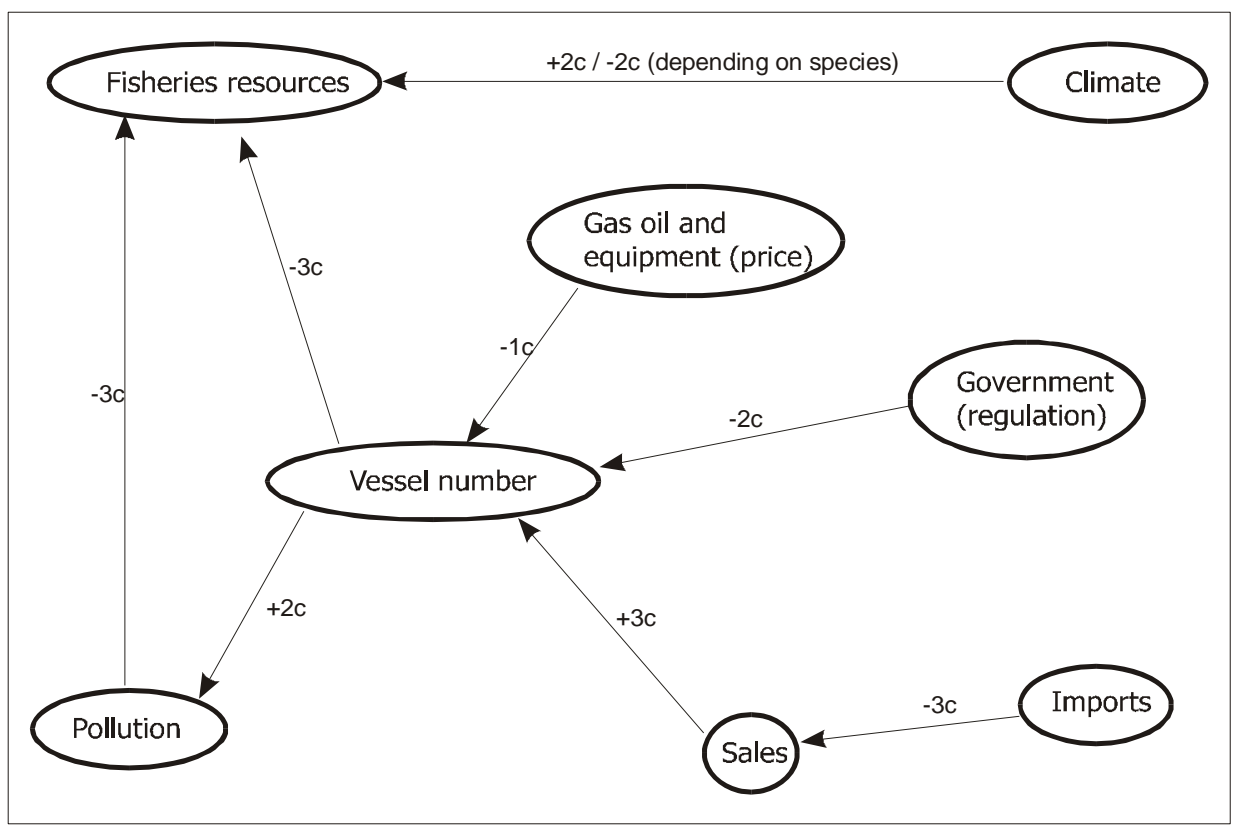

Legend

Relative strength :

1: low

2: medium

3: high

Time scale :

a: short term

b: medium term

c: long term

Figure 2

Fig. 2. Example cognitive map. 

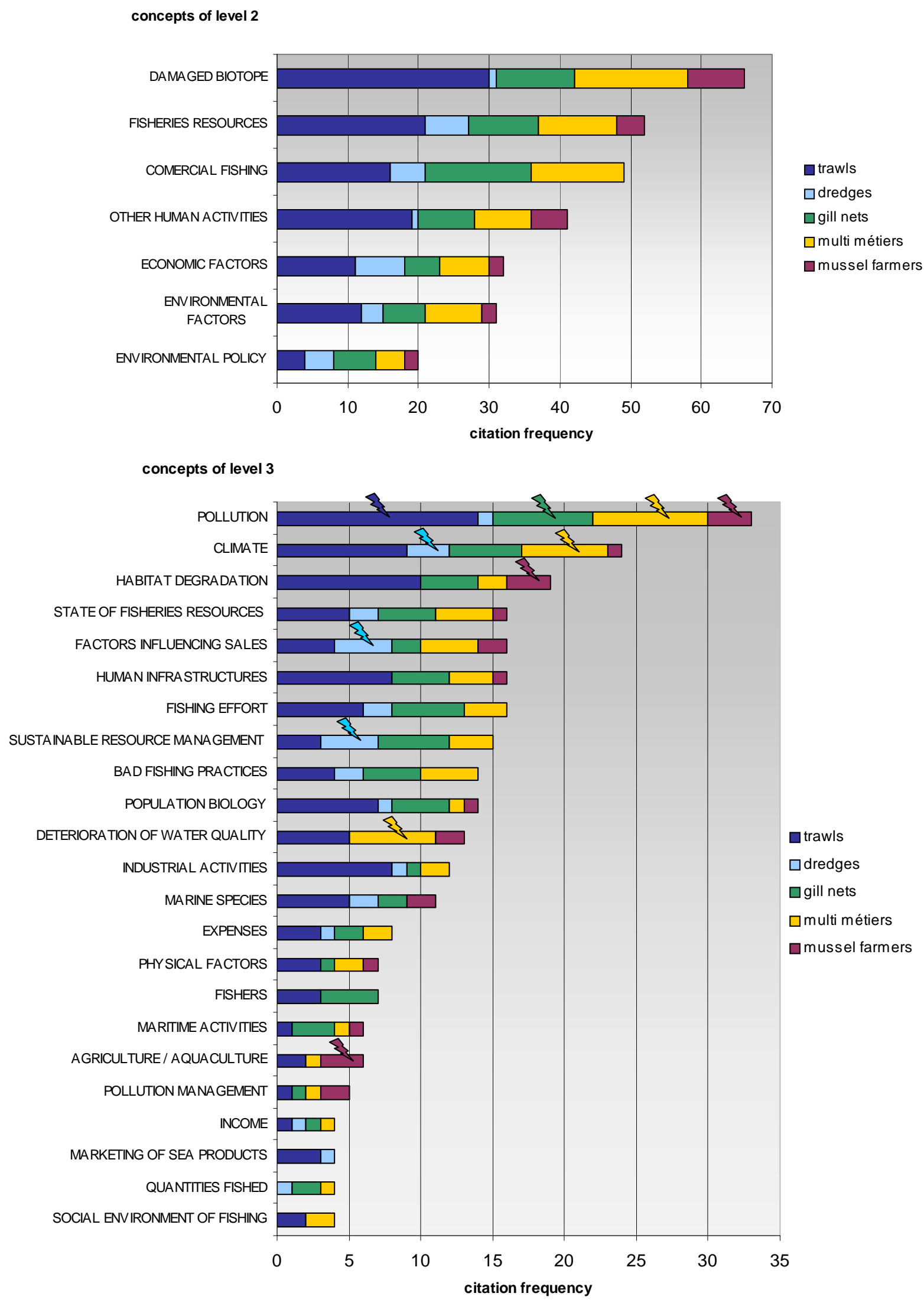

Fig. 3. Citation frequencies per métier of terms of level 2 and 3 of the ontology derived from cognitive maps. Flashes: terms representing more than $10 \%$ of all citations at level 3 and 4 . See Appendix 2 for a description of the ontology. 


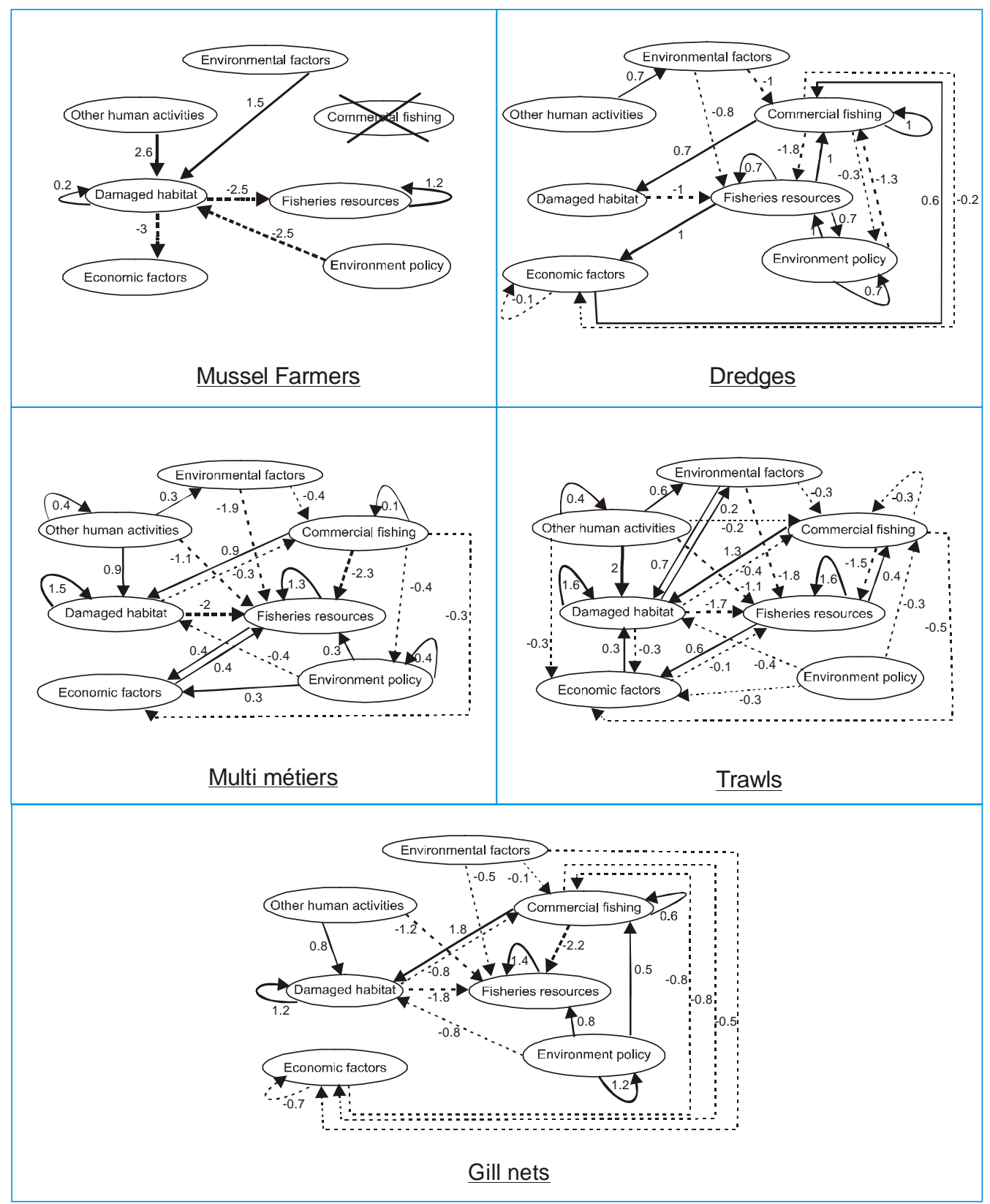

Fig. 4. Average cognitive maps per métier. Crossed out concepts mean that no interviewee mentioned them. 
Number of concepts

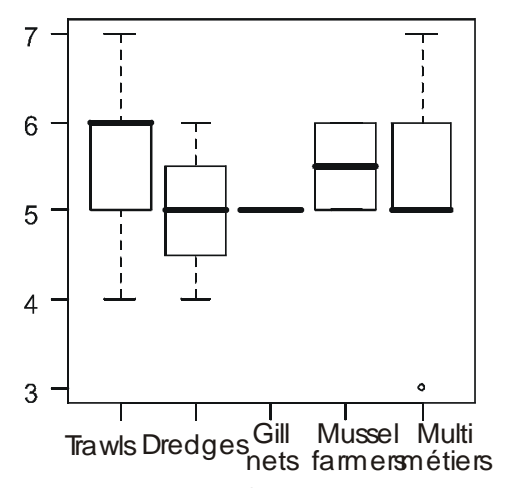

Number of connections

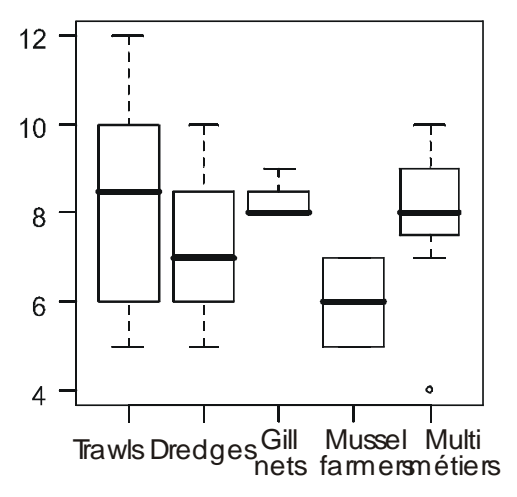

Density

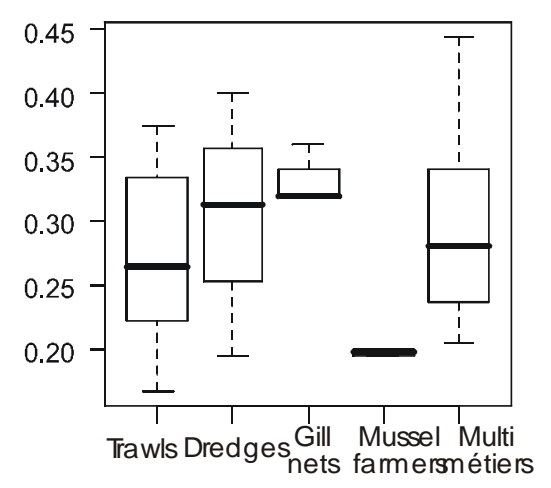

Fig. 5. Descriptors of individual cognitive maps for each métier. 


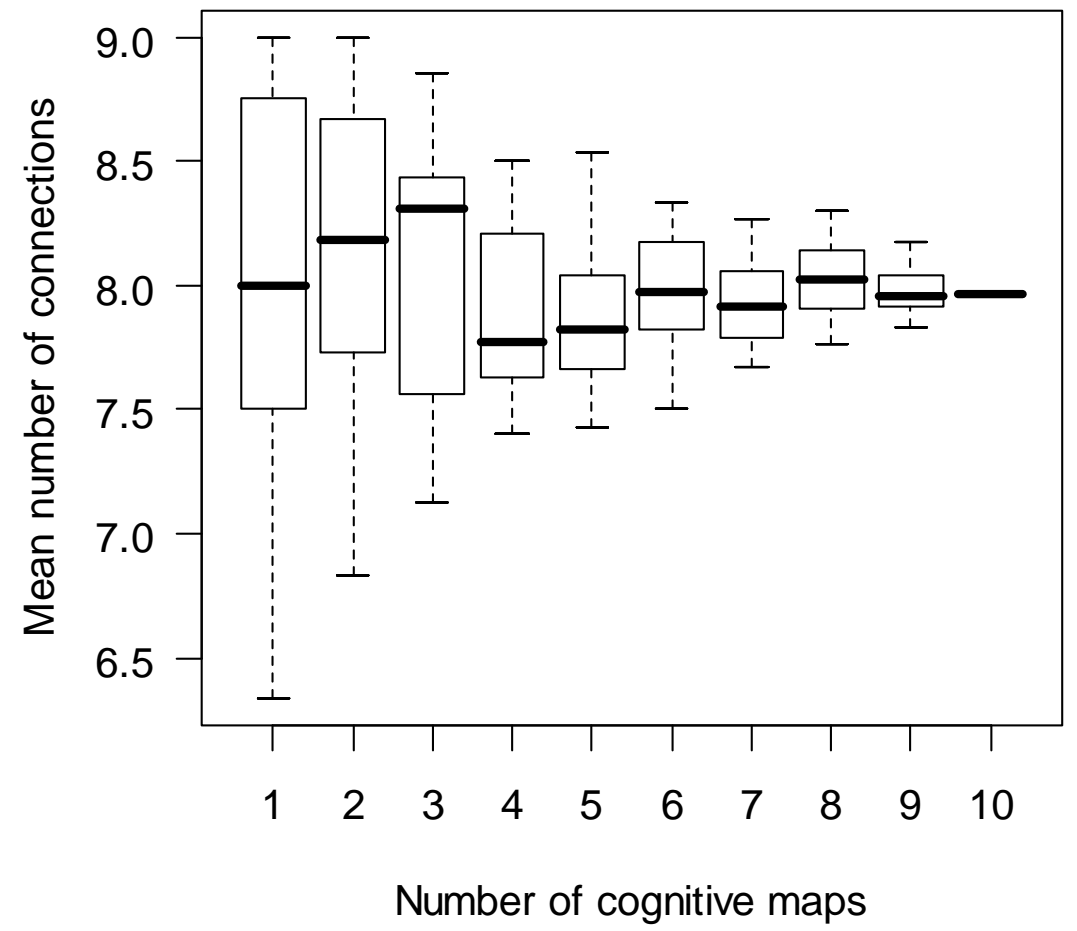

Fig. 6. Mean number of connections per cognitive map as a function of sample size obtained for the trawl métier by resampling without replacement.

\section{Appendix 1: Interview protocol}

\section{Topic 1: Reference system}

How long have you been fishing in the Eastern Channel?

Which fishing gears do you use?

Which species do you target?

Can you draw on this map the outline of what you call the Eastern Channel? In which areas do you fish?

\section{Topic 2: Current state of the ecosystem}

How do you see the current state of the Channel ecosystem (resource and habitat)?

Which signs, or indicators, tell you this?

Has the ecosystem changed and how?

How do you explain these changes?

Which species illustrate these changes? Which do not?

Which factors and human activities are influencing this ecosystem?

\section{Topic 3: Management objectives and current measures}

What do you think about the current management measures in the Channel? Are they effective?

Which environmental, economic and social objectives would you like to see being implemented for the Channel fisheries management?

\section{Topic 4: The future}

How do you see the future of the Channel (in 5 to 10 years)? 
What should be primarily protected?

What should be avoided?

On which topics do you expect scientists to contribute?

\section{Appendix 2: Ontological tree with four levels and three principal branches or systems.}

\section{MARINE ECOSYSTEM}

\subsection{FISHERIES RESOURCES}

5.1.1.

1.1.1.1

1.1.1.2

5.1.2.

1.1.1.3

1.1.1.4

1.1.1.5

1.1.1.6

1.1.1.7

1.1.1.8

5.1.3.

1.1.1.9

1.1.1.10

1.1.1.11

1.1.1.12

MARINE SPECIES

fish

shellfish

POPULATION BIOLOGY

fish presence in area

strong fish concentrations

fish reproduction

fish size

food availability

absence of predators

STATE OF FISHERIES RESOURCES

reduction of the overfishing

protection of juveniles

protection of spawning grounds

absence of parasites

\subsection{DAMAGED HABITAT}

5.2.1.

HABITAT DEGRADATION

1.1.1.13

1.1.1.14

degraded sea bottom

silting-up

1.1.1.15

proliferation of spartina $s p$.

5.2.2.

1.1.1.16

1.1.1.17

DETERIORATION OF WATER QUALITY

hypoxia

algal development - "green tides"

5.2.3.

POLLUTION

1.1.1.18

1.1.1.19

1.1.1.20

1.1.1.21

1.1.1.22

1.1.1.23

6. SOCIAL SYSTEM 


\subsection{COMMERCIAL FISHING}

6.1.1.

1.1.1.24

1.1.1.25

1.1.1.26

1.1.1.27

1.1.1.28

1.1.1.29

1.1.1.30

1.1.1.31

6.1.2.

1.1.1.32

6.1.3.

1.1.1.33

1.1.1.34

1.1.1.35

6.1.4.

1.1.1.36

1.1.1.37

6.1.5.

1.1.1.38

1.1.1.39

1.1.1.40
FISHING EFFORT

number of vessels

number of fishing licences

fishers' density

number of target species

vessel size

number of fishing trips

fishing time

fishing zones

QUANTITIES FISHED

quantities fished

BAD FISHING PRACTICES

undersized fish

discards

destructive fishing gear

FISHERS

fishers

foreign fishers

SOCIAL ENVIRONMENT OF FISHING

good working conditions

technological developments

agreement between fishers

\subsection{OTHER HUMAN ACTIVITIES}

6.2.1.

1.1.1.41

1.1.1.42

1.1.1.43

6.2.2.

1.1.1.44

1.1.1.45

1.1.1.46

6.2.3.

1.1.1.47

1.1.1.48

1.1.1.49

1.1.1.50

6.2.4.

1.1.1.51

1.1.1.52

1.1.1.53

1.1.1.54

1.1.1.55
AGRICULTURE IAQUACULTURE

agriculture

sheep farming

aquaculture

MARITIME ACTIVITIES

recreational fishing

maritime traffic

harbours

INDUSTRIAL ACTIVITIES

industries

nuclear power stations

oilfields

gravel extraction

HUMAN INFRASTRUCTURE

various human infrastructure

Channel tunnel

Port 2000 (extension of Le Havre harbour)

offshore wind farms

underwater cables

\subsection{ECONOMIC FACTORS}

6.3.1.

1.1.1.56

1.1.1.57

6.3.2.

1.1.1.58

1.1.1.59
MARKETING OF SEA PRODUCTS

fish sales

sales of the fishers of Boulogne sur mer

FACTORS INFLUENCING SALES

markets

demand 

1.1.1.60
1.1.1.61
imports
1.1 .1 .62
price of fish
1.1.1.63
commercial quality of fishery products
consumer society
6.3.3.
EXPENSES
1.1.1.64
1.1.1.65
various expenses/taxes
fuel price
6.3.4.
INCOME
1.1.1.66
income

6.4. ENVIRONMENTAL POLICY

6.4.1.

SUSTAINABLE RESOURCE MANAGEMENT

1.1.1.67

1.1.1.68

1.1.1.69

1.1.1.70

1.1.1.71

1.1.1.72

1.1.1.73

stock management conservation of resources research

regulation of fishing activities

selective fishing gear controls of fishing activities penalties

6.4.2.

POLLUTION MANAGEMENT

1.1.1.74

antipollution standards water treatment plants control (pollution)

\section{EXTERNAL FACTORS}

\subsection{ENVIRONMENTAL FACTORS}

7.1.1.

1.1.1.77

1.1.1.78

1.1.1.79

1.1.1.80

1.1.1.81

7.1.2.

1.1.1.82

1.1.1.83

1.1.1.84

1.1.1.85
CLIMATE

global warming
high water temperature
drought
bad weather
wind

PHYSICAL FACTORS

currents

spring tides

floods

cliff erosion 